\title{
The Influence of Integrated Organic and Inorganic Fertilizers on Forage Yield and Nutritive Value of Maize and Soil Properties
}

\author{
Muhammad Ibrahim ${ }^{1}$, Muhammad Jameel ${ }^{1}$, Tanveer Ul Haq ${ }^{2}$, Mubashar Nadeem ${ }^{3}$, Muhammad Ishaq Asif Rehmani ${ }^{1}$, Anam Noreen \\ Abbas $^{4}$, Shakeel Ahmad ${ }^{5}$, Muhammed Atif Shabir ${ }^{6}$, Muhammad Mazhar Iqbal ${ }^{7}$, Leonard M. Lauriault ${ }^{8}$ \\ ${ }^{1}$ Department of Agronomy, Faculty of Agricultural Sciences, Ghazi University, Dera Ghazi Khan, Pakistan \\ ${ }^{2}$ Department of Soil Science, Muhammad Nawaz Shareef University of Agriculture, Multan, Pakistan \\ ${ }^{3}$ Department of Agronomy, College of Agriculture, University of Sargodha, Sargodha, Pakistan \\ ${ }^{4}$ Department of Entomology, University of Agriculture, Faisalabad, Pakistan \\ ${ }^{5}$ Department of Agronomy, Bahauddin Zakariya University, Multan, Pakistan \\ ${ }^{6}$ Cotton Research Sub Station, Rajanpur, Pakistan \\ ${ }^{7}$ Soil \& Water Testing Laboratory, Department of Agriculture, Government of Punjab, Chiniot, Punjab \\ ${ }^{8}$ Rex E. Kirksey Agricultural Science Center, New Mexico State University, Tucumcari, NM, USA 88401
}

\author{
Article History \\ Received: 26.11 .2020 \\ Accepted: 10.12 .2020 \\ Published: 16.12 .2020 \\ Journal homepage: \\ http://www.easpublisher.com
}

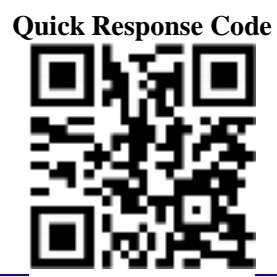

\begin{abstract}
High forage yield and nutritive value are critical to livestock production in semiarid regions where poor soil fertility and low organic matter are significant challenges for forage production. A randomized complete block study with three replications was conducted at Faisalabad, Pakistan, to compare the effects of organic (OF) and inorganic (IF) fertilizer in various ratios on soil properties and the production of forage maize (Zea mays). Treatments included the $100 \%$ recommended IF d o se (110-60-100kg N-P $\left.\mathrm{O}_{5}-\mathrm{K}_{2} 0 \mathrm{ha}^{-1}\right), 100 \%$ dose of cattle manure (CM, $\left.20 \mathrm{t} \mathrm{ha}^{-1}\right)$, $100 \%$ dose of poultry manure (PM, $\left.5 \mathrm{t} \mathrm{ha}^{-1}\right), 75 \% \mathrm{IF}+25 \% \mathrm{OF}(75 \mathrm{IF} / 25 \mathrm{CM}$ or PM), $50 \% \mathrm{IF}+50 \% \mathrm{OF}(50 \mathrm{IF} / 50 \mathrm{CM}$ or $\mathrm{PM}), 25 \% \mathrm{IF}+75 \% \mathrm{OF}(25 \mathrm{IF} / 75 \mathrm{CM}$ or $\mathrm{PM})$, and an unfertilized control (OIF/0OF). The OF improved soil properties when applied 45 before sowing and incorporated. Maize growth variables and dry matter (DM) yield were maximized with $25 \mathrm{IF} / 75 \mathrm{PM}(6.17,7.06,8.24,8.99,7.90,8.23,8.53,9.43,8.39$, and $8.20 \mathrm{t} \mathrm{ha}^{-1}$ for $0 \mathrm{IF} / 1 \mathrm{OF}, 100 \mathrm{IF} / 0 \mathrm{OF}, 75 \mathrm{IF} / 25 \mathrm{C}, 75 \mathrm{IF} / 25 \mathrm{PM}, 50 \mathrm{IF} / 50 \mathrm{CM}, 50 \mathrm{IF} / 50 \mathrm{PM}$, 25IF/75CM, 25IF/75PM, 0IF/100CM, and 0IF/100PM, respectively, $\mathrm{LSD}_{0.05}=0.57$ ). Organic fertilizer, especially PM, improved the soil characteristics. In addition, the integrated nutrient package 25IF/75PM (27.5-15-25 N-P $\left.\mathrm{O}_{5}-\mathrm{K}_{2} \mathrm{O} \mathrm{ha}^{-1}+3.75 \mathrm{tha}^{-1} \mathrm{PM}\right)$ gave a greater maize forage yield with good nutritive value.

Keywords: Cattle manure, Forage maize, Inorganic fertilizer; Nutritive value, Organic fertilizer, Poultry manure, Soil properties.
\end{abstract}

Copyright (C) 2020 The Author(s): This is an open-access article distributed under the terms of the Creative Commons Attribution 4.0 International License (CC BY-NC 4.0) which permits unrestricted use, distribution, and reproduction in any medium for non-commercial use provided the original author and source are credited.

\section{INTRODUCTION}

Livestock is the major component of agriculture in semi-arid regions globally. Forage is the cheapest source of energy and its adequate supply is considered the guarantee of a healthy livestock industry. Many forage crops are grown in winter as well as in summer, but maize is more succulent and palatable than other summer cereal forages [1] and it is highly relished by the animals [2] due to its high nutritive value [3]. An adequate supply of soil nutrients is essential for optimum growth and development of maize [4]. Low forage yield of maize is mainly attributed to unsuitable sowing methods, sowing of low yielding varieties, inadequate moisture supply, and imbalanced soil fertility [5]. Poor soil fertility and low organic matter (OM) are considered real problems for forage production in semi-arid soils [6].
The addition of organic amendments to restore soil $\mathrm{OM}$ is rarely given importance to overcome nutrient deficiencies because of the convenience of applying inorganic products [7]; however, cost of the inorganic products has increased, and the organic sources are readily available. Soil fertility, water holding capacity, drainage and aeration, and the ultimate enhancement of forage yield and nutritive value may be improved by application of CM and PM [8-10] that must be disposed of in an environmentally appropriate manner.

The objective of this study was to evaluate various IF and OF combinations for soil improvement and maize forage production under the agro-ecological conditions of semi-arid regions such as Pakistan.

Materials ANd Methods 


\section{Site Information}

A field experiment was conducted during the summer season to determine the effect of organic and inorganic fertilizers on soil properties and maize forage yield and nutritive value. This study was carried out at the research area of College of Agriculture, Dera Ghazi Khan sub Campus, University of Agriculture, Faisalabad, Pakistan. The soil was a sandy loam with an electrical conductivity (EC) of $4.4 \mathrm{dS} \mathrm{m}{ }^{-1}, \mathrm{pH}$ of 8.8 , phosphorus $(4 \mathrm{ppm})$, potassium $(140 \mathrm{ppm})$, and $0.37 \%$ OM, with low water holding capacity. The climatic conditions of the area are arid to semi-arid where annual rainfall was insufficient to meet crop water requirements. Consequently, the only local source available for irrigation, brackish groundwater, was used as needed to supplement precipitation.

\section{Treatments}

Organic fertilizers were collected from nearby villages and analyzed before the application (Table-1).

Table-1: Composition of organic manure fertilizers (CM from cattle and PM from poultry) applied to forage maize at Faisalabad, Pakistan

\begin{tabular}{|l|l|l|}
\hline Characteristic & CM & PM \\
\hline $\mathrm{pH}$ & 7.79 & 7.60 \\
\hline $\mathrm{EC}$ & 0.55 & 0.26 \\
\hline $\mathrm{N}(\%)$ & 1.81 & 2.16 \\
\hline $\mathrm{P}(\%)$ & 0.94 & 1.24 \\
\hline $\mathrm{K}(\%)$ & 0.92 & 0.81 \\
\hline Organic carbon $(\%)$ & 24.18 & 15.29 \\
\hline $\mathrm{C} / \mathrm{N}$ & 13.25 & 7.64 \\
\hline
\end{tabular}

T reatments included the $100 \%$ recommended IF dose (110-60-100kg N- $\mathrm{P}_{2} \mathrm{O}_{5}-\mathrm{K}_{2} 0 \mathrm{ha}^{-1}$, 100IF/OOF), $100 \%$ dose of OF $\left(\mathrm{CM}=20 \mathrm{t} \mathrm{ha}^{-1}\right.$, $0 \mathrm{IF} / 100 \mathrm{CM} ; \mathrm{PM}=5 \mathrm{t} \mathrm{ha}^{-1}, 0 \mathrm{IF} / 100 \mathrm{PM}$; collectively 0IF/100OF), $75 \% \mathrm{IF}+25 \% \mathrm{OF}(75 \mathrm{IF} / 25 \mathrm{CM}$ or $\mathrm{PM}$; collectively 75IF/25OF), $50 \% \mathrm{IF}+50 \%$ OF (50IF/50CM or PM; collectively 50IF/50OF), $25 \% \mathrm{IF}+$ $75 \%$ OF (25IF/75CM or PM; collectively $75 \mathrm{IF} / 25 \mathrm{OF})$, and an unfertilized control (0IF/0OF).

\section{Test Management}

Plots, $1.5 \mathrm{~m} \times 5 \mathrm{~m}$, were laid out in randomized complete block design with three replications. During conventional seedbed preparation, organic fertilizers were applied to their respective plots according to the treatment plan and mixed thoroughly with the soil 45 days before sowing to allow them to be decomposed completely. Maize (cv Pak-Afgoi) was sown using a single-row hand drill on a well-prepared seedbed at $100 \mathrm{~kg}$ seed $\mathrm{ha}^{-1}$ in $30 \mathrm{~cm}$ rows on $29 \mathrm{July}$. The inorganic fertilizer $\mathrm{N}, \mathrm{P}$, and $\mathrm{K}$ were applied as urea, diammonium phosphate, and sulfate of potash, respectively. For inorganic fertilizer treatments, half the $\mathrm{N}$ dose and the full doses of $\mathrm{P}_{2} \mathrm{O}_{5}$ and $\mathrm{K}_{2} \mathrm{O}$ were applied at the time of sowing and the remaining half of the $\mathrm{N}$ dose was applied 25 days after sowing (DAS).
Irrigations with brackish groundwater were applied seven days after complete seed germination, again at the four leaf stage, and finally after three weeks of crop growth. Predominant pests were termite (Microtermes obesi) and shoot fly (Atherigonna reversura) at the early maize growth stages and stem borer (Chilo partellus) during later maize growth stages. The maize shoot fly was controlled with Carbofuran. Weeds were controlled by manual hoeing twice.

\section{Measurements}

Soil sampling pre-sowing and post-harvesting was done with a soil augur at three different points within each plot, which were thoroughly mixed to form a composite sample. Saturated soil paste $\mathrm{pH}$ was measured with a portable $\mathrm{pH}$ meter (Method 21a, [11]) and EC was measured with a digital conductivity meter (Method 3a and 4b) [11]. Soil P, K, and OM were determined by following the procedures given in Ryan et al. [12].

Seven DAS, all plants were counted within a $1-\mathrm{m}^{-2}$ quadrat in each plot. Immediately prior to harvesting, the height of five randomly selected plants from each plot was measured from ground to the tip of the longest leaf. Stem diameter was calculated as the average of measurements taken with a Vernier caliper from the base, middle, and top portion of these plants. Leaves were removed from these plants with scissors and counted. A representative sample of leaves $(10 \mathrm{~g})$ was used to calculate the leaf area manually according to the following equation $[13,14]$ :

Leaf area $=\mathrm{L}(\mathrm{cm}) \times \mathrm{W}(\mathrm{cm}) \times 0.75$,

Where $\mathrm{L}$ and $\mathrm{W}$ are leaf length and width in centimeters, respectively, and 0.75 is correction factor for maize fodder.

Harvesting was done on 4 October, 65 DAS, when the crop attained about $50 \%$ tasseling. A selected area $(1.5 \mathrm{~m} \times 5 \mathrm{~m})$ of each plot was harvested manually with a sickle and weighed in the field. Five plants were selected randomly and weighed separately to obtain subsample fresh weight. These subsamples were then sundried in the field for 5 days before being placed in forced-air oven at $70^{\circ} \mathrm{C}$ for 72 hours, after which their dry weight was recorded to calculate dry weight per plant, DM content, and DM yield. The oven-dried whole plant samples were ground to pass a 1-mm screen and analyzed for crude protein (CP) and ash according to AOAC methods [15].

\section{Statistical Analysis}

Soil characteristics and maize crop growth and forage yield and nutritive value data were analyzed by using CO-STAT (Cohort Software, Birmingham, UK). Fisher's Analysis of Variance (ANOVA) and least significant differences (LSD) were applied at the 5\% 
probability level to compare treatment means when differences were observed [16].

\section{RESUlTS AND DisCUSSION Soil Data}

Results of soil characteristics analyses are shown in Table-2. Differences between treatments in pre-sowing samples are likely associated with treatment application timing such that incorporating the manure treatments 45 days before sowing was effective in reducing $\mathrm{EC}$ and increasing $\mathrm{P}, \mathrm{K}$, and $\mathrm{OM}$, while there was no significant effect on $\mathrm{pH}$. Among the manure treatments, pre-sowing soil phosphorus with PM was increased more than pre-sowing soil P of CM (Table-2). Conversely, pre-sowing soil $\mathrm{K}$ was greater at all IF/OF ratios when $\mathrm{CM}$ was applied compared to $\mathrm{PM}$. Additionally, soil OM was greater when $\mathrm{CM}$ was the organic fertilizer source compared to when PM was the source (Tables-1 and 2). That CM contains more OM content than other manures has been reported elsewhere [17].

Post-harvest EC was influenced by fertilizer treatments such that the addition of OF reduced soil EC increasingly as the proportion of $\mathrm{OF}$ increased compared to the unfertilized control (0IF/0OF) and the full rate of fertilizer (100IF/0OF) (Table-2). Postharvest soil $\mathrm{pH}$ was influenced by fertilizer treatments such that there was an apparent increase in $\mathrm{pH}$ when manure was not applied, while there was little change as the proportion of OF increased until the proportion of $\mathrm{OF}$ increased to $100 \%$, which led to an apparent decrease in soil pH (Table-2). Overall, soil phosphorus, potassium, and $\mathrm{OM}$ were lower across treatments, compared to the pre-sowing sample, but ranking did not change (Table-2).

Salinity is a major issue of semiarid regions that may be mitigated by the application of organic fertilizers as well as integrated nutrient management [22]. The decrease in EC might be due to the positive effects manure applications, particularly CM, have in mitigating the negative influence of the salts on soil [17, 18]. The increase in the EC of soil after harvesting over EC before sowing, in most cases (Table-2), might be due to the irrigation with brackish water [19], which had greater EC $\left(4.98 \mathrm{dS} \mathrm{m}^{-1}\right)$. The reason for low $\mathrm{pH}$ (Table2) was likely the addition of OF [19, 20]. Minimum soil $\mathrm{pH}$ was observed where $\mathrm{PM}$ and $\mathrm{CM}$ were used as the only fertilizers in tomato culture [20]. The increase in available $\mathrm{P}$ (Table-2) might be due to the greater proportion of $\mathrm{P}$ in the PM (Table-1) [21]. Our results regarding potassium (Table-2) are consistent to the reports of others $[17,20]$ that $\mathrm{CM}$ contains a greater concentration of the potassium than other manures. Our OM contents (Table-2) also are corroborated [17] that level of $\mathrm{OM}$ is greater in $\mathrm{CM}$ than other $\mathrm{OF}$ sources (Table-1).

Table-2: Pre-sowing and post-harvest soil characteristics as influenced by the application of organic [OF: cattle manure (CM) or poultry manure (PM)] and inorganic (IF) fertilizers to forage maize in various ratios at Faisalabad, Pakistan. Values are the means of three replications

\begin{tabular}{|c|c|c|c|c|c|c|c|c|c|c|}
\hline \multirow{2}{*}{$\begin{array}{l}\text { Fertilizer/ } \\
\text { Manure } \\
\text { Ratio }^{1} \\
\end{array}$} & \multicolumn{5}{|c|}{ Pre-sowing } & \multicolumn{5}{|c|}{ Post-harvest } \\
\hline & $\mathbf{E C}^{2}$ & pH & $\mathbf{P}$ & $\mathbf{K}$ & $\mathbf{O M}$ & EC & pH & $\mathbf{P}$ & $\mathbf{K}$ & OM \\
\hline & $\mathrm{dS} / \mathrm{m}^{-}$ & - & ppm & ppm & $\%$ & $\mathrm{dS} / \mathrm{m}$ & - & $\mathrm{ppm}$ & $\mathrm{ppm}$ & $\%$ \\
\hline OIF/0OF & $4.38 \mathrm{a}^{3}$ & $8.81 \mathrm{a}$ & $4.0 \mathrm{e}$ & $140 \mathrm{c}$ & $0.37 \mathrm{i}$ & $4.47 \mathrm{a}$ & $9.07 \mathrm{ab}$ & $2.33 \mathrm{~d}$ & $119 \mathrm{c}$ & $0.11 \mathrm{f}$ \\
\hline 100IF/0OF & $4.05 \mathrm{ab}$ & $8.72 \mathrm{a}$ & $8.0 \mathrm{~cd}$ & $181 b$ & $0.42 \mathrm{hi}$ & $4.17 \mathrm{ab}$ & $9.16 \mathrm{a}$ & $3.67 \mathrm{c}$ & $146 \mathrm{~b}$ & $0.32 \mathrm{~cd}$ \\
\hline $75 \mathrm{IF} / 25 \mathrm{CM}$ & $3.37 \mathrm{bc}$ & $8.76 a$ & $7.5 \mathrm{~d}$ & 196a & $0.67 \mathrm{de}$ & $3.42 \mathrm{~cd}$ & $8.95 \mathrm{ab}$ & $3.67 \mathrm{dc}$ & $165 \mathrm{a}$ & $0.31 \mathrm{~cd}$ \\
\hline $75 \mathrm{IF} / 25 \mathrm{PM}$ & $3.16 \mathrm{~cd}$ & $8.78 \mathrm{a}$ & $8.3 \mathrm{~cd}$ & $176 b$ & $0.49 \mathrm{gh}$ & $3.49 \mathrm{bc}$ & $8.83 \mathrm{abc}$ & $4.80 \mathrm{ab}$ & $146 b$ & $0.13 \mathrm{ef}$ \\
\hline $50 \mathrm{IF} / 50 \mathrm{CM}$ & $3.16 \mathrm{~cd}$ & $8.80 \mathrm{a}$ & $8.1 \mathrm{~cd}$ & 200a & $0.78 \mathrm{c}$ & $3.27 \mathrm{~cd}$ & $8.82 \mathrm{abc}$ & $4.33 \mathrm{bc}$ & $167 \mathrm{a}$ & $0.38 \mathrm{c}$ \\
\hline 50IF /50PM & $3.26 \mathrm{bc}$ & $8.68 \mathrm{a}$ & $9.0 \mathrm{bc}$ & $175 b$ & $0.56 f g$ & $3.35 \mathrm{~cd}$ & $8.71 \mathrm{abc}$ & $4.83 \mathrm{ab}$ & $143 b$ & $0.23 \mathrm{de}$ \\
\hline $25 \mathrm{IF} / 75 \mathrm{CM}$ & $2.86 \mathrm{~cd}$ & $8.66 \mathrm{a}$ & $7.6 \mathrm{~d}$ & $204 a$ & $0.87 \mathrm{~b}$ & $2.99 \mathrm{cde}$ & $8.85 \mathrm{ab}$ & $4.33 b c$ & $165 \mathrm{a}$ & $0.55 b$ \\
\hline $25 \mathrm{IF} / 75 \mathrm{PM}$ & $3.08 \mathrm{~cd}$ & $8.78 \mathrm{a}$ & $9.9 b$ & $179 \mathrm{~b}$ & $0.62 \mathrm{ef}$ & $3.11 \mathrm{cde}$ & $8.86 \mathrm{ab}$ & $5.46 a$ & $141 \mathrm{~b}$ & $0.30 \mathrm{~cd}$ \\
\hline 0IF/100CM & $2.39 \mathrm{~d}$ & $8.23 b$ & $8.4 \mathrm{~cd}$ & $203 a$ & $1.20 \mathrm{a}$ & $2.48 \mathrm{e}$ & $7.84 \mathrm{~d}$ & $5.17 \mathrm{ab}$ & $173 \mathrm{a}$ & $0.83 a$ \\
\hline 0IF/100PM & $2.98 \mathrm{~cd}$ & $8.71 \mathrm{a}$ & $11.1 \mathrm{a}$ & $183 b$ & $0.72 \mathrm{~cd}$ & 2.70de & $8.02 \mathrm{~cd}$ & $5.60 \mathrm{a}$ & $138 b$ & $0.37 \mathrm{c}$ \\
\hline $\mathrm{LSD}_{0.05}$ & 0.85 & 0.41 & 1.1 & 9 & 0.08 & 0.73 & 0.82 & 0.89 & \begin{tabular}{l|l}
9 \\
\end{tabular} & 0.11 \\
\hline
\end{tabular}

${ }^{1}$ For Fertilizer/Manure Ratio treatments, $100 \mathrm{IF} / 0 \mathrm{OF}$ signifies the percentage of the full IF rate $\left(110-60-100 \mathrm{~kg} \mathrm{~N}-\mathrm{P}_{2} \mathrm{O}_{5^{-}}\right.$ $\mathrm{K}_{2} \mathrm{O} \mathrm{ha}^{-1}$ ) and the full OF rates of 20 and $5 \mathrm{t} \mathrm{ha}^{-1}$ for CM or PM, respectively.

${ }^{2} \mathrm{EC}, \mathrm{OM}$, and $\mathrm{LSD}_{0.05}$ signify electrical conductivity, organic matter, cattle manure, poultry manure, and least significant difference at $\mathrm{P}<0.05$, respectively.

${ }^{3}$ Means within a column followed by the same letter are not significantly different based on the $\operatorname{LSD}_{0.05}$.

\section{Plant Data}

Plant-based data are shown in Table-3. The results showed that maximum numbers of plant of maize were germinated when 0IF/100CM was applied, although it was not significantly greater than several other treatments, including 0IF/100PM and 25IF/75CM, which were significantly greater than only $0 \mathrm{IF} / 0 \mathrm{OF}$ (Table-3). Similar results were reported elsewhere [22] for organic manures, especially $\mathrm{CM}$, that add OM to soil (Table-1), thereby, improving water holding 
capacity, porosity, and structure, and ultimately germination of maize (Table-3).

Similar trends existed for plant height, stem diameter, number of leaves per plant, leaf area, and plant dry weight, such that, applying any fertilizer increased the measurement over the $0 \mathrm{IF} / 0 \mathrm{OF}$ treatment (Table-3). Additionally, among treatments receiving organic fertilizer, those with PM were greater than those with CM, with few exceptions (Table-3). One common exception is that $0 \mathrm{IF} / 100 \mathrm{CM}$ was usually greater than 0IF/100PM (Table-3).

Inorganic $\mathrm{P}$ increases plant height in maize [23], which supports our results that the application of any fertilizer increased plant height (Table-3) [24, 25]. Increased plant height of forage sorghum [Sorghum bicolor L. (Moench)] compared to the control due to integration of PM with inorganic fertilizer was also reported elsewhere $[1,26]$.

Our stem diameter results (Table-3) are in line with the conclusion of others [27] who reported that combinations of organic and inorganic fertilizers significantly increased the stem girth in maize. Similarly, organic amendments along with application of inorganic fertilizer increased stem diameter of maize sown [28]. Integrating PM with IF increased the stem diameter of forage sorghum compared to the control
[26], although, others [7] reported that IF produced the thickest maize plant.

Our results pertaining that $25 \% \mathrm{PM}+75 \% \mathrm{SSP}$ increased number of leaves in maize plants (Table-3) are corroborated with findings elsewhere for maize [29], okra (Abelmoschus esculentus L.) [30], and amaranth (Amaranthus spp.) [31]. Similar results to ours for leaf area (Table-3) were also reported by others $[22,32]$.

The increase in dry weight per plant of forage maize for PM compared to CM, except for at the 0IF/100OF rates (Table-3) have been reported [32], such that, PM, along with IF, increased dry weight per plant in maize. The increase might be due to the positive response of maize to the integrated and continuously slow availability of nutrients. Furthermore, plant height, stem diameter, number of leaves per plant, and leaf area are contributory factors to increase the dry weight per plant.

\section{Forage Yield and Nutritive Value}

Forage is the ultimate source of food for livestock. Greater values for plant height, stem diameter, number of leaves, and leaf area that influenced dry weight per plant also contributed to differences in forage yield of maize (Table-3) [7, 3234], as well as forage sorghum [2] and maize - sesbania (Sesbania sesban L.) mixtures [35].

Table-3: Plant parameters of forage maize as influenced by the application of organic [OF: cattle manure (CM) or poultry manure (PM)] and inorganic (IF) fertilizers applied in various ratios at Faisalabad, Pakistan. Values are the means of three replications

\begin{tabular}{|c|c|c|c|c|c|c|c|c|c|}
\hline $\begin{array}{l}\text { Fertilizer/ } \\
\text { Manure } \\
\text { Ratio }^{1}\end{array}$ & $\begin{array}{l}\text { Germinat } \\
\text { ion }\end{array}$ & $\begin{array}{l}\text { Plant } \\
\text { height }\end{array}$ & $\begin{array}{l}\text { Stem } \\
\text { diameter }\end{array}$ & Leaves & $\begin{array}{l}\text { Leaf } \\
\text { area }\end{array}$ & $\begin{array}{l}\text { Dry } \\
\text { weight }\end{array}$ & Yield & $\begin{array}{l}\text { Crude } \\
\text { protein }\end{array}$ & Ash \\
\hline & Plants $/ \mathrm{m}^{2}$ & $\mathrm{~cm}$ & $\mathrm{~cm}$ & No/plant & $\mathrm{cm}^{2} /$ plant & g/plant & t DM/ha & $\%$ & $\%$ \\
\hline OIF/0OF & $23.3 c^{2}$ & $141 \mathrm{~g}$ & $1.51 \mathrm{f}$ & $11.7 \mathrm{~d}$ & $197 \mathrm{~h}$ & $31.57 \mathrm{~h}$ & $6.17 \mathrm{f}$ & $7.93 c$ & $8.76 \mathrm{~d}$ \\
\hline 100IF/0Of & $24.3 \mathrm{bc}$ & $185 c$ & $1.63 \mathrm{e}$ & $13.3 \mathrm{bc}$ & $272 f$ & $46.00 \mathrm{~g}$ & $7.06 \mathrm{e}$ & $8.71 \mathrm{~b}$ & $9.75 \mathrm{c}$ \\
\hline $75 \mathrm{IF} / 25 \mathrm{CM}$ & $24.7 \mathrm{abc}$ & $200 \mathrm{a}$ & $1.90 \mathrm{c}$ & $13.0 \mathrm{bcd}$ & $267 \mathrm{~g}$ & $69.90 \mathrm{~b}$ & $8.24 \mathrm{~cd}$ & $9.21 \mathrm{ab}$ & $9.97 b c$ \\
\hline $75 \mathrm{IF} / 25 \mathrm{PM}$ & $24.3 b c$ & $201 \mathrm{a}$ & $2.03 \mathrm{~b}$ & $14.3 \mathrm{ab}$ & $289 b c$ & $73.00 \mathrm{a}$ & 8.99ab & $9.18 \mathrm{ab}$ & $10.15 b$ \\
\hline $50 \mathrm{IF} / 50 \mathrm{CM}$ & $24.3 b c$ & $167 \mathrm{e}$ & $1.62 \mathrm{e}$ & $12.0 \mathrm{~cd}$ & $283 d$ & $54.68 \mathrm{f}$ & $7.90 \mathrm{~d}$ & $9.15 \mathrm{ab}$ & $9.92 b c$ \\
\hline 50IF/50PM & $24.7 \mathrm{abc}$ & $181 \mathrm{~d}$ & $1.72 \mathrm{~d}$ & $12.3 \mathrm{~cd}$ & $269 f g$ & $57.84 \mathrm{e}$ & $8.23 \mathrm{~cd}$ & $9.12 \mathrm{ab}$ & $9.86 \mathrm{c}$ \\
\hline $25 \mathrm{IF} / 75 \mathrm{CM}$ & $25.0 \mathrm{ab}$ & $160 \mathrm{f}$ & $1.59 \mathrm{e}$ & $12.0 \mathrm{~cd}$ & $295 b$ & $64.92 \mathrm{c}$ & $8.53 b c$ & $9.29 a$ & $9.91 b c$ \\
\hline 25IF/75PM & $24.3 b c$ & $202 a$ & $2.11 \mathrm{a}$ & $15.3 \mathrm{a}$ & $298 \mathrm{a}$ & $79.30 \mathrm{a}$ & $9.43 \mathrm{a}$ & $9.40 \mathrm{a}$ & $10.32 \mathrm{a}$ \\
\hline 0IF/100CM & $26.0 \mathrm{a}$ & $200 \mathrm{a}$ & $2.01 \mathrm{~b}$ & $14.0 \mathrm{ab}$ & $279 \mathrm{e}$ & $66.52 \mathrm{c}$ & $8.39 \mathrm{~cd}$ & $9.16 \mathrm{ab}$ & $9.91 b c$ \\
\hline 0IF/100PM & $25.0 \mathrm{ab}$ & $192 b$ & $1.87 \mathrm{c}$ & $13.0 \mathrm{bcd}$ & $289 \mathrm{c}$ & $62.77 \mathrm{~d}$ & $8.20 \mathrm{~cd}$ & $9.48 \mathrm{a}$ & $10.35 \mathrm{a}$ \\
\hline $\mathrm{LSD}_{0.05}{ }^{3}$ & 1.5 & 3 & 0.05 & 1.4 & 4 & 2.05 & 0.57 & 0.50 & 0.28 \\
\hline
\end{tabular}

${ }^{1}$ For Fertilizer/Manure Ratio treatments, the numbers signify the percentage of the full IF rate (110-60-100 $\mathrm{kg} \mathrm{N}-\mathrm{P}_{2} \mathrm{O}_{5}-\mathrm{K}_{2} \mathrm{O}$ $\mathrm{ha}^{-1}$ ) and the full OF rates of 20 or $5 \mathrm{tha}^{-1}$ for CM or PM, respectively.

${ }^{2}$ Means within a column followed by the same letter are not significantly different based on the $\operatorname{LSD}_{0.05}$.

${ }^{3} \mathrm{LSD}_{0.05}$ signifies least significant difference at $\mathrm{P}<0.05$.

Soil fertility plays a vital role in improving the nutritive value of the forage maize. As expected, applying fertilizers increased the $\mathrm{CP}$ content of the maize forage (Table-3). At the higher rates of 75 and $100 \%$ OF, PM had numerically greater CP than CM. The increase in CP (Table-3) is likely due to greater concentration of nitrogen in the sources used in the present study (Table-1) [35-37]. Applying fertilizers also increased the ash content of the maize forage without regard to the fertilizer source (Table-3), which has been reported elsewhere [36]. 


\section{Conclusions}

Organic fertilizer, especially PM, improved the soil characteristics. In addition, the integrated nutrient package 25IF/75PM (27.5-15-25 N- $\mathrm{P}_{2} \mathrm{O}_{5}-\mathrm{K}_{2} \mathrm{O}$ ha $^{-1}+$ $\left.3.75 \mathrm{t} \mathrm{ha}^{-1} \mathrm{PM}\right)$ gave a greater forage yield with good nutritive value of maize.

\section{ACKNOWLEDGMENT}

The authors appreciate the research support by Soil and Water Testing Lab for Research and Department of Agronomy, Faculty of Agricultural Sciences, Ghazi University, both in Dera Ghazi Khan, Pakistan. Salary and research support for L.M.L. were provided by state and federal Hatch funds appropriated to the New Mexico Agricultural Experiment Station.

\section{REFERENCES}

1. Ahmad, M., Hussain, N., Jan, A., Ahmad, K., \& Hussain, S. (2007). Response of maize to phosphorus levels and plant density. Sarhad Journal of Agriculture, 23, 51-57.

2. Ibrahim, M., Ayub, M., Maqbool, M. M., Nadeem, S. M., Ul Haq, T., Hussain, S., Ali, A., \& (2014). Lauriault, L. M. Forage yield components of irrigated maize-legume mixtures at varied seed ratios. Field Crops Research, 169, 140-144.

3. Ibrahim, M., Ayub, M., Tanveer, A., \& Yaseen, M. (2012). Forage quality of maize and legumes as monocultures and mixtures at different seed ratios. Journal of Animal and Plant Sciences, 22, 987992.

4. Cox, W. J., Kalonge, S., Cherney, D. J. R., \& Red, W. S. (2007). Growth, yield and quality of forage maize under different nitrogen management practices. Agronomy Journal, 5, 341-347.

5. Ibrahim, M., Tahir, M., Noorka, I. R., Maqbool, M. M., Hussain, S., Bashir, M. A., Qaisrani, T. B., Safder, E., \& Lauriault, L. M. (2016). Effect of seed proportions on growth and forage yield of maize sown alone in mixture with three legumes. International Journal of Agricultural and Applied Sciences, 8, 48-53.

6. Sarwar, G., Schmeisky, H., Hussain, N., Muhammad, S. Ibrahim, M., \& Safdar, E. (2008). Improvement of soil physical and chemical properties with compost application in rice-wheat cropping system. Pakistan Journal of Botany, 40, 275-282.

7. Rehmani, M. I. A. (2006). Impact of organic and inorganic sources of fertilizers on the growth and yield of fodder maize (Zea mays L.). M.Sc. (Hons.) Agric. Thesis, Agron. Dept., Univ. Agric.: Faisalabad, Pakistan.

8. Kuepper, G., \& Gegner, L. (2007). 2004 Organic crop production overview. Butte, MT, USA: ATTRA National Center for Appropriate Technology. Available online. https://attra.ncat.org/attra- pub/download.php?id=66 (accessed on 9 March 2018).

9. Chang, C., Sommerfeldt, T. G., \& Entz, T. (1991). Soil Chemistry after eleven annual application of cattle feedlot manure. Journal of Environmental Quality, 20, 475-480.

10. Chung, R., Wang, C. H., Wang, Y., Wang, R. S., Wang, C. W., \& Wang, Y. T. (2000). Influence of organic matter and inorganic fertilizer on the growth and nitrogen accumulation of corn plants. Journal of Plant Nutrition, 23, 297-311.

11. U.S. Salinity Lab. (1954). Diagnosis and improvement of saline and alkali soils. Hand book 60, pp 94-106. Washington, DC, USA: USDA.

12. Ryan, J., Estefan, G., \& Rashid, A. (2001). Soil and plant analysis laboratory manual. $2^{\text {nd }} \mathrm{Ed}$., pp 123-134. Aleppo, Syria: International Center for Agricultural Research in the Dry Areas (ICARDA)

13. Pearce, R.B., Mock, J. H., \& Bailey, T. B. (1975). Rapid method for estimating leaf area per plant in maize. Crop Scence, 15, 691-694.

14. Dwyer, L. M, \& Stewart, D. W. (1986). Leaf area development in field grown maize. Agronomy Journal, 78, 334-343.

15. AOAC. (1990). Official methods of analysis. $15^{\text {th }}$ edition. Washington DC, USA: Association of Official Analytical Chemists.

16. Steel, R. G. D., Torrie, J. H, \& Dickey, D. A. (2007). Principles and procedures of statistics. A biometrical approach, 3rd Ed. New York, NY, USA: McGraw Hill Book Co.

17. Bharadwaj, A., Khandelwal, V., Choudhary, P., \& Bhatia, A. K. (2011). Comparative studies of organic enrichers in the improvement of physicochemical and microbiological characteristics of saline/usar soils. Journal of Chemical and Pharmaceutical Research, 3, 9971003.

18. Munir, A., Hassan, A., Nawaz, S., \& Bajwa, M. A. (2012). Farm manure improved soil fertility in mungbean-wheat cropping system and rectified the deleterious effects of brackish water. Pakistan Journal of Agricultural Sciences, 49, 511-519.

19. Malik, M. A. (2014). Effectiveness of organic amendments for improving physico-chemical properties of soil and chickpea (cicer arietinum) growth irrigated with brackish water. M.Sc. (Hons.) Agric. Thesis, Soil. Sci. Dept., Univ. Agric.: Faisalabad, Pakistan.

20. Ewulo, B. S., Ojeniyi, S. O., \& Akanni, D. A. (2008). Effect of poultry manure on selected soil physical and chemical properties, growth, yield and nutrient status of tomato. African Journal of Agricultural Research, 3, 612-616.

21. Ullah, M. S., Islam, M. S., Islam, M. A., \& Haque, T. (2008). Effects of organic manures and chemical fertilizers on the yield of brinjal and soil properties. Journal of the Bangladesh Agricultural University, 6, 271-276. 
22. Aziz, T., Ullah, S., Sattar, A., Nasim, M., Farooq, M., \& Khan, M. M. (2010). Nutrient availability and maize (Zea mays L.) growth in soil amended with organic manures. International Journal of Agriculture and Biology, 12, 621-624.

23. Masood, T., Gul, R., Munsif, F., Jalal, F., Hussain, Z., Noreen, N., Khan, H., Din, N., \& Khan, H. (2011). Effect of different phosphorus levels on the yield and yield components of maize. Sarhad Journal of Agriculture, 27, 167-170.

24. Mitchell, C. C., \& Tu, S. (2005). Long term evaluation of poultry litter as a source of nitrogen for cotton and corn. Agronomy Journal, 97, 399407.

25. Warren, J. G., Phillips, S. B., Mullins, G. L., Keahey, D., \& Penn, C. J. (2006). Environmental and production consequences of using alumamended poultry litter as a nutrient source for corn. Journal of Environmental Quality, 35, 172182.

26. Ismaeil, F. M., Abusuwar, A. O., \& Naim, A. M. E. (2012). Influence of chicken manure on growth and yield of forage Sorghum (Sorghum bicolor L. Moench). International Journal of Agriculture and Forestry, 2, 56-60.

27. Ayeni, L. S., Adeleye, E. O., \& Adejumo, J. O. (2012). Comparative effect of organic, organomineral and mineral fertilizers on soil properties, nutrient uptake, growth and yield of maize (Zea mays). International Research Journal of Agricultural Science and soil Science, 2, 493497.

28. Xiang, R., Jiang, M., Rong, J., Hong, Z., Qiang, M. L., Fuqiang, Z., Hua, Y. Z. (2001). Effects of application of inorganic fertilizer in combination with organic fertilizer to red upland soil. Journal of Hunan Agricultural University, 27, 453-456.

29. Ali, M., A. Ali, M. Tahir, \& M. Yaseen. (2012). Growth and Yield Response of Hybrid Maize through Integrated Phosphorus Management. Pakistan Journal of life and Social Sciences, 10, 59-66.
30. Prabu, T., Narwadkar, P. R., Sanindranath, A. K., \& Rafi, M. (2003). Effect of integrated nutrient management on growth and yield of okra cv. Parbhani Kranti. Orissa Journal of Horticulture, 31, 17-21.

31. Deksissa T., Short, I., \& Allen, J. (2008). Effect of soil amendment with compost on growth and water use efficiency of Amaranth. In: Proc. UCOWR/NIWR Annual Conf. Int. Water Res. Challenges for the 21st Century and Water Resources Education, July 22-24, 2008. Durham, NC, USA.

32. Adeniyan, O. N., \& Ojeniyi, S. O. (2005). Effect of poultry manure, NPK 15-15-15 and combination of their reduced levels on maize growth and soil chemical properties Nigerian Journal of Soil Science, 15, 34-41.

33. Hirzel, J., Matus, L., Novoa, F., \& Walter, I. (2007). Effect of poultry litter on silage maize (Zea mays L.) production and nutrient uptake. Spanish Journal of Agricultural Research, 5, $102-$ 109.

34. Debelle, T., \& Friessen, D. K. (2001). Effect of enriching farmyard manure with mineral fertilizer on grain yield of maize at Bako, western Ethiopia. Seventh Eastern and Southern African Maize Conference. February 11-15, 2001. pp. 335-337.

35. Nadeem, M. A., Iqbal, Z., Ayub, M., Mubeen, K., \& Ibrahim, M. (2009). Effect of nitrogen application on forage yield and quality of maize sown alone and in mixture with legumes. Pakistan Journal of Life and Social Sciences, 7, 161-167.

36. Ahmad, W., Ahmad, A. U. H., Zameer, M. S. I., Afzal, M., Mohsin, A. U., Khalid, F., \& Gillani, S. M. W. (2012). Qualitative and quantitative response of forage maize cultivars to sowing methods under subtropical conditions. Journal of Animal and Plant Sciences, 22, 318-323.

37. Hani, A. E., Hamad, M. A., \& Ali, E. E. (2006).The effect of nitrogen and phosphorus fertilization on growth, yield and quality of forage maize. Journal of Agronomy, 5, 515-518. 